\title{
Compound Words: Implementation in English Language Teaching
}

\author{
${ }^{1}$ Muhammad Gilar Yudha Pratama \\ ${ }^{1}$ Mataram University, Mataram, Indonesia \\ muhammadgilaryudha@gmail.com
}

\begin{tabular}{|c|c|}
\hline Article Info & Abstract \\
\hline $\begin{array}{l}\text { Article History } \\
\text { Received:July 12, } 2018 \\
\text { Accepted: September } 30, \\
2018 \\
\text { Keywords } \\
\text { ELT; } \quad \\
\text { Compound } \\
\text { Linguistics. Words; Applied }\end{array}$ & $\begin{array}{l}\text { Teaching English in Indonesia is implemented through the teaching of EFL } \\
\text { (English as a foreign language). Teaching and learning English as a second } \\
\text { language poses a challenge for both teachers and students. Problems that } \\
\text { arise such as lack of student motivation, changing curriculum, monotonous } \\
\text { learning, lack of teacher creativity, and lack of linguistic knowledge in } \\
\text { teaching become a separate issue. This article describes the role linguistic } \\
\text { morphology plays in teaching and learning English in the classroom. It } \\
\text { particularly describes the challenge of combining simple compound words } \\
\text { with morphological forms created by the teacher. This teaching design will } \\
\text { be applied to } 7 \text { th grade junior high school students. This simple design will } \\
\text { introduce how to combine noun and adjective using the daily context } \\
\text { familiar to the students. } \\
\text { The researcher expects to see the challenges the teachers will face during the } \\
\text { application of the design in the classroom and how they create ways to deal } \\
\text { with the challenges. }\end{array}$ \\
\hline $\begin{array}{l}\text { Support by: } \\
\text { dol } 1 \text { Crossref }\end{array}$ & This is an open access article under the CC-BY-SA license \\
\hline
\end{tabular}

\section{INTRODUCTION}

English has been regarded as the first foreign language in Indonesia. Its function is to foster country and nation's development, to build relationships with other countries, and to run foreign policy including as a language used for broader communication in international forums. In relation to this, Indonesia has implemented EFL (English as a foreign language) teaching at almost the school level, starting from elementary to high school. However, because it is only a foreign language, there are many problems found in English language teaching.

The problem that appears in the environment of education is a fact about how the English lesson is still often regarded as something that is frightening to students. The various reasons that are often encountered are hard-to-understand lessons, not their daily language, the confusing teacher, lazy to open the dictionary, the boring lessons, the unattractive way of teaching the teacher, and various other reasons. In the end, they are less interested in their English lessons. We can imagine such boring class conditions during the teaching and learning process. Some are sleepy, and others who are willing to think and do only a few students. Therefore it takes creative learning and active teachers to achieve effective and joyful in English language teaching.

In this paper, we will attempt to outline how the relationship between morphological learning as a branch of linguistics with the teaching of English in Indonesia. The topic discussed here is the use of compound words in English language teaching in first-grade of junior high school children. This will be further explained in the sub-chapter of English morphology application and teaching discussions in this 
section of the paper. So hopefully the results obtained from morphological learning in English teaching in Indonesia can overcome the problems that occur above.

\section{METHOD}

As already described in the early part of this paper that the problem of mastering English learning in Indonesia is not only happening to the students but the problem also occurs in the teaching of the teacher. A number of people judge the teaching of English in Indonesia is too rigid. This condition triggers many obstacles among students to improve their English skills. Although it has long been included in the curriculum of education in the country, many students admitted that they often face problems when learning English. Therefore, teachers are advised to have an active role in finding techniques and teaching methods are fun and make students more quickly make out and understand the material taught.

While many of us may not like to admit it, many children do not always like the idea of being in the classroom to learn a new language. Even more, as teachers, we all know that even most attentive children can get bored and occasionally lose focus. Incorporating an English game is a great way to get out of the habit of language training, spreadsheets, boring repetition and individual learning. If you can find ways to keep children interested in the classroom (i.e. through fun English games), they will also find that they are interested in the topic - and will often absorb and retain more knowledge than if they just learn to pass the exam or completing a task. Therefore it is in line with the expectation of the implementation of the 2013 curriculum that guides students much more action from their teachers and the liveliness of teachers here only as facilities and student support to achieve the goal. In addition, it is also to answer the questions that appear at the beginning of this paper: "What kind of English teaching and activity is appropriate?" So we will try to answer how the learning morphology of English especially teaching compound words to be fun and not quickly make students feel bored.

There are some fun variations in teaching compound words. The easiest game to introduce compound words is "letter tiles". To give us a little idea of how the game "Letter tiles", will be given a series of learning activities as follows:

Letter Tiles - (Rippel 2018)

1) The first step teacher takes on many letters can be either verbs or adjectives, write them on small paper and make them into small pieces of tiles, i.e. bath tub

2) Tell students that this "bath tub" has 2 small words of the same color, and hook them to find the pair from the set of words.

Learning by "Letter tiles" method is very encouraging for students to keep actively inquiring and it is a fun learning activity. Interesting things that can be found in this learning method, that student can separate the compound words into two words "bath" and "Tub". It can be practiced with other examples such as sandbox, anthill, backpack, and windmill. This method is great for helping students to understand how compound words are formed.

Some games and other activities such as "Bird Friends" Activity, "Chop Chop" Activity, "Banana Split" Activity has many variations and methods are much more fun in learning compound words. To complete this paper and as knowledge of how the stages teach compound words with games, the entire games and activities are attached to the appendices section.

The last but not the least, the students here are not to be asked to distinguish between the compound words. Students here only learn to recognize nouns, adjectives and try to form simple compound words together. So the pattern used here is the 
pattern of habit and memorization indirectly. Teachers here can help spell each word and provide confirmation help that this is a sentence that contains compound words. At the end of this paper is also attached a simple story that contains many compound words. Therefore, with a fun way of learning compound words will be felt very fun for students

\section{RESULT}

In the implementation of learning compound words in English teaching is far from perfection. The writer realizes that there are several problems that occur as follows: (1) To begin with, the lack of student motivation is believed to be one of the main problems with learning English. This may be due to students' perceptions of English. Due to the nature of a language hardly found in Bahasa, many of them consider it a difficult lesson to learn. As a result, they missed the class, and when they attended the class, it was not because they wanted to learn English, but probably because they were afraid to fail. In addition, many of them may be less attentive during class, chatting with classmates, scribbling on their notebooks or gasping in their textbooks. (2) Furthermore, insufficient time is another matter in compound words. Time in Class is often very short; it's once or twice a week, an hour or two every day for lots of teaching materials. Therefore, lesson plans not developed as programmed are the next class and often review of the last unfinished teaching-learning process. If this situation persists, the teacher will fail to achieve the predetermined goal. To make it worse, they will also fail to recognize the problems that exist in the student learning process. They consequently cannot solve it because it is difficult to distinguish certain learners with specific learning problems in a very limited time.

In summary, the above problems are common and specific problems in learning compound words in English teaching. Therefore teachers should also use their creativity to recognize limitations and constraints, and collectively make efforts to overcome and find ways to overcome the frustrating problems that exist.

\section{CONCLUTION}

We come to the conclusion that the implementation of morphological learning in English teaching is very useful. As a result teaching compounds words is very fun with various activities and games. Although, the fact that teaching English in Indonesia is not an easy way to apply. In line with that the immature curriculum that keeps changing every year, student motivation, and teacher readiness in providing an active role in all English learning. But finally everything can be solved if everything goes back to teachers who have a lot of experience and creativity to continue to develop ideas and methods for teaching English in the future.

\section{REFERENCE}

[1] Basiran, Mokh. 1999. Apakah yang Dituntut GBPP Bahasa Indonesia Kurikulum 1994. Yogyakarta: Depdikbud

[2] E. Roulet. 1975. Linguistic approaches in applied linguistics. Paris: Didier

[3] Hanafi, Nurachman. 2002. Morphology (hand-outs of lectures). Mataram: FKIP Unram.

[4] Hanafi, Nurachman. 2015. Morphological Typology (hand-outs of lectures). Mataram: FKIP Unram.

[5] Katamba, Francis. 1993. Morphology. Cambridge: CUP. 
[6] Konsep dan Kurikulum 2013 in https://kemdikbud.go.id/kemdikbud/dokumen/Paparan/Paparan\%20Wamendik.p df accessed on 9 July 2018

[7] Mackey, W. F. 1965. Language Teaching Analysis. London: Longman Group Ltd.

[8] O'Grady, W., et al. 1991. Contemporary Linguistics: An Introduction. New York: St. Martin's Press.

[9] Parera, Jos Daniel. 1991. Kajian Linguistik Umum Historis Komparatif dan Tipologi Struktural. Jakarta: Erlangga

[10] Rippel, Marrie. 2018. The Essential Guide to Teaching Compound Words in https://blog.allaboutlearningpress.com/compound-words/

[11] http://downloads.allaboutlearningpress.com/downloads/501-CompoundWords-for-Kids.pdf

[12] http://downloads.allaboutlearningpress.com/downloads/Blog Samples/AARL1-Lesson40-Bird-Friends.pdf

[13] http://downloads.allaboutlearningpress.com/downloads/Blog Samples/AARL1-Lesson40-Chop-Chop.pdf

[14] http://downloads.allaboutlearningpress.com/downloads/Banana-SplitsGame.pdf

[15] http://downloads.allaboutlearningpress.com/downloads/AAR-L1-Cobweb-theCat.pdf accessed on 2 July 2018

[16] Silabus Bahasa Inggris K13 Edisi Revisi 2017 in https://drive.google.com/file/d/0BzWAaQofM8dbVzNUTjB2MUVTS2c/view accessed on 9 July 2018

[17] Suriasumantri, Jujun. 2009. Filsafat Ilmu: Sebuah Pengantar Populer. Jakarta: Pustaka Sinar Harapan.

[18] Štekauer, Pavol, et al. 2012. Word-Formation in the World's Languages: $A$ Typological Survey. New York: Cambridge University Press. 